УДК 347.615

DOI https: / / doi.org/10.32837/yuv.v0i4.993

\author{
О. Адамова, \\ кандидат юридичних наук, доцент, \\ доцент кафедри цивільного права \\ Національного університету «Одеська юридична академія»
}

\title{
ДО ПИТАННЯ ПРО ОБОВ'ЯЗОК БАТЬКІВ УТРИМУВАТИ ДИТИНУ
}

\begin{abstract}
Правовідносини батьків та дітей щодо утримання - це правовідносини, в яких одна сторона зобов'язана надати другій стороні утримання на підставах і в порядку, що встановлені законом, а друга сторона вправі вимагати виконання такого обов'язку. Зобов'язання батьків відносно дітей щодо утримання залежно від самої управомоченої особи поділяються на: 1) зобов'язання батьків щодо утримання дитини до досягнення нею повноліття (глава 15 CK України); 2) зобов'язання батьків щодо утримання повнолітніх дочки, сина (глава $16 \mathrm{CK}$ України) [1].

Обов'язок утримувати дитину - це моральне i найважливіше правове зобов'язання батьків. Батьки зобов'язані утримувати свою дитину незалежно від того, одружені вони чи розлучені; цей обов'язок зберігається i у тому разі, коли дитина народилася у шлюбі, який згодом було визнано недійсним. Цей обов'язок не припиняється й у разі позбавлення батьків батьківських прав.

У зв'язку 3 особливим станом дитини як особи, що через свій вік потребує певної матеріальної підтримки та захисту, окреме значення мають зобов'язання батьків щодо утримання дитини до досягнення нею повноліття. Обов'язок утримувати дитину є таким, що нерозривно пов'язаний 3 особою матері та батька, а тому: 1) за життя батьків він не може бути перекладений на іншу особу. Додатковий (субсидіарний) обов'язок діда та баби утримувати
\end{abstract}

внука - це їхній самостійний обов'язок, що виникає 3 окремої підстави, тому не $є$, відповідно до цивілістичної термінології, - переведенням обов'язку на іншу особу; 2) після смерті матері чи батька він не входить до складу спадщини, у зв'язку з чим не може перейти до спадкоємців; 3) батьківський обов'язок утримувати дитину триває до іï повноліття. Якщо, наприклад, дочка одружилася у 15 років, це означає, що вона набула повної цивільної дієздатності, але не стала повнолітньою, отже іï право на утримання триватиме й надалі. Відповідно до ст. 6 СК України правовий статус дитини має особа до досягнення нею повноліття.

Юридичний склад, який є передумовою виникнення аліментних обов'язків батьків щодо дітей, виглядає наступним чином:

1) кровне споріднення між батьками і дітьми, посвідчене в установленому законом порядку чи інших юридично значимих зв'язків між ними (правовідносини щодо усиновлення);

2) віку особи, яку батьки повинні утримувати.

Деякі науковці вважають, що до юридичного складу, що $€$ підставою виникнення, може входити також такий юридичний факт, як договір на утримання неповнолітньої дитини у грошовій та (або) натуральній формі, який батьки можуть укласти між собою [2]. Також, відповідно до ст. 190 CK України, той із батьків, з ким проживає дитина, і той із батьків, хто проживає окремо від неї, з дозволу органу опіки 


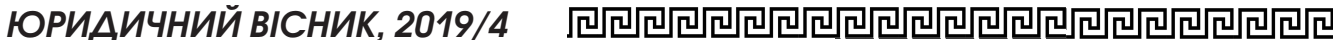

та піклування можуть укласти договір про припинення права на аліменти для дитини у зв'язку 3 передачею права власності на нерухоме майно (житловий будинок, квартиру, земельну ділянку тощо) [1]. Вважаємо, що такий юридичний факт буде скоріш підставою для зміни, а не для виникнення аліментних зобов'язань, адже аліментне зобов'язання вже існує, виникаючи 3 моменту народження дитини.

$\mathrm{У}$ той же час, перепоною виникненню аліментних правовідносин будуть обставини, що звільняють батьків від сплати аліментів, а саме, зазначена у ст. 188 CK України можливість, коли дохід дитини набагато перевищує дохід кожного з них і забезпечує повністю їі потреби. Доречно відмітити рішення Кременецького районного суду Тернопільської області, в якому чітко зазначено, що отримання доходу дітьми, який нехай i забезпечує їх потреби, але не перевищує доходів аліментозобов'язаної особи (за рішенням отримувана дітьми стипендія), не звільняє батьків від виплати аліментів [3].

Крім добровільного порядку сплати аліментів на дитину, законодавство встановлює ще й судовий порядок, який ініціюється за заявою зацікавлених осіб. Справи про стягнення аліментів на дітей вважаються найбільш поширеною категорією справ, які випливають із сімейних правовідносин.

При визначенні розміру аліментів суд обов'язково з'ясовує всі обставини справи та враховує стан здоров'я і матеріальне становище дитини, стан здоров'я та матеріальне становище платника аліментів, наявність у нього інших дітей, непрацездатних членів сім’і та інші обставини, що мають істотне значення. Мінімальний розмір аліментів на дитину не може бути меншим за 50 відсотків прибуткового мінімуму для дитини відповідного віку, який щорічно затверджується відповідно до Закону України «Про Державний бюджет України». Отже, законодавством не визначена верхня межа розміру аліментів на дитину.
3 липня 2017 р. сімейне законодавство доповнено нормою, згідно з якою, той $з$ батьків або інших законних представників дитини, разом з яким проживає дитина, має право звернутися до суду із заявою про стягнення аліментів у розмірі: на одну дитину $-1 / 4$, на двох дітей - $1 / 3$, на трьох і більше дітей $50 \%$ заробітку (доходу) платника аліментів, але не більше 10 прожиткових мінімумів на дитину відповідного віку.

Наразі аліменти, одержані на дитину $€$ власністю дитини, вона має право брати участь у використанні або самостійно розпоряджуватися аліментами на іï утримання відповідно до Цивільного кодексу України. Контроль за цільовим використанням в інтересах дитини аліментів здійснює орган опіки та піклування як за власного ініціативою, так і за заявою платника аліментів. У разі нецільового використання таких коштів платник має право звернутися до суду з позовом про зменшення розміру аліментів або про внесення їх частини на особистий рахунок дитини. Як правило, аліменти сплачуються батьками щомісяця, на кожну неповнолітню дитину незалежно від того, де вона знаходиться. Влаштування дитини до закладу охорони здоров'я, навчального або іншого закладу, де утримання надається дитині $з$ державного бюджету, не припиняє стягнення аліментів на користь того з батьків, з ким проживає дитина.

Існує ряд факторів, які впливають на ступінь матеріальної відповідальності того із батьків, хто проживає із дитиною. До них належить виховання і турбота про дитину, ведення домашнього господарства на благо дитини, а також і той факт, що в більшості випадків той з батьків, 3 ким залишається дитина, змушений постійно працювати, щоб отримати кошти для власного існування та існування дитини. Відповідно, коло обов'язків у такої особи значно ширше від тої, яка не проживає разом iз дитиною (проживає поза сім'єю) та сплачує тільки кошти на утримання. Це повинно бути враховане при визна- 
ченні розміру аліментів, що підлягають сплаті.

CK України передбачає можливість зменшення та збільшення розміру аліментів. Так, відповідно до ч. 1 ст. 192 СК України розмір аліментів, визначений за рішенням суду або за домовленістю між батьками, може бути згодом зменшено або збільшено за позовом платника або одержувача аліментів [1]. Перелік обставин, які можуть слугувати підставами для зменшення або збільшення розміру аліментів, є невичерпним - це зміна матеріального чи сімейного стану платника або одержувача аліментів, погіршення або поліпшення здоров'я когось із них або інші обставини.

Взагалі, одним з найбільш дискусійним у сімейному праві до останнього часу є питання встановлення_оптимального розміру аліментів на неповнолітніх дітей. 3 данного приводу Л.П. Короткова зазначає, що за сучасних економічних умов порядок законодавчого визначення розміру аліментів у частці від заробітку (доходу) був би архаїчним, оскільки існував за радянських часів і розрахований на середній заробіток (доходи) в умовах відсутності різкого соціального розшарування[4]. Л.В. Афанасьева, навпаки, стверджує, що законодавцю не слід було відмовлятись від стягнення аліментів у певній, визначеній у законі частці до заробітку (доходу). На їі думку, це б максимально забезпечило права дитини і розвантажило суди від зайвої роботи [5]. На наш погляд, мінімальний розмір утримання, встановлений у законі, не достатньо виконує свою функцію забезпечення прав дітей - його слід підвищити у сучасних економічних умовах. Але встановлення в законі утримання у частці від заробітку, вважаємо, було б зайвим, адже у випадку надзвичайно маленького доходу, дитина не буде отримувати необхідних для існування коштів, а у випадку великих доходів $€$ висока вірогідність того, що вони будуть йти не тільки на забезпечення дитини.
Якщо платник аліментів має нерегулярний, мінливий дохід, частину доходу одержує в натурі, а також за наявності інших обставин, що мають істотне значення, суд за заявою платника або одержувача може визначити розмір аліментів у твердій грошовій сумі. Якщо розмір аліментів, визначений судом або за домовленістю між батьками у твердій грошовій сумі, то він підлягає індексації відповідно до закону.

До обставин, які враховуються судом при визначенні розміру аліментів, береться до уваги i майно, яким володіє або користується особа, i запроваджується витратний метод розрахунку доходів платника аліментів.

Тобто, якщо ми знаємо, що особа має тіньовий дохід, але немає офіційного доходу, або офіційний дохід явно нижчий, а неофіційний набагато більший, стягувач аліментів тепер може в суді довести факт витрат. Якщо платник аліментів їдить на дорогому автомобілі, чи живе в елітній квартирі, іздить на відпочинок за кордон, суд це повинен врахувати.

Більше того, враховується не тільки факт володіння майном, але і користування ним. Тобто вводиться принцип винаймаєш квартиру в центрі міста або позичив іномарку на деякий час, то і на аліменти знайдеш гроші [6].

В боржника $є$ право після отримання судового наказу про стягнення аліментів на звернення до суду з позовом, про зменшення суми аліментів. У такому випадку увесь тягар доказування необхідності зменшення аліментів лягає на іх платника.

Законом передбачено, що той із батьків або інших законних представників дитини, разом з яким проживає дитина, має право звернутися до суду із заявою про видачу судового наказу про стягнення аліментів у розмірі 50 відсотків прожиткового мінімуму для дитини відповідного віку.

Якщо особа хоче стягнути більше аліментів, ніж 50 відсотків, то вона може це зробити, довівши в класич- 


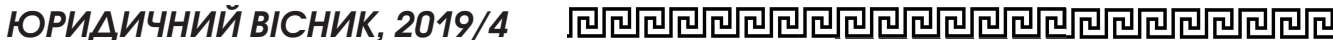

ному позовному проваджені свої збільшені вимоги.

Відповідно до ст. 181 СК України, якщо місце проживання батьків невідоме, або вони ухиляються від сплати аліментів, або не мають можливості утримувати дитину, дитині призначається тимчасова державна допомога, яка не може бути меншою ніж 30 відсотків прожиткового мінімуму для дитини відповідного віку. Виплата тимчасової державної допомоги здійснюється за рахунок коштів Державного бюджету України. Порядок призначення та виплати затверджений постановою [7]. Суми наданої дитині тимчасової державної допомоги підлягають стягненню 3 платника аліментів до Державного бюджету України у судовому порядку.

Окрім цього, Законом України «Про державну допомогу сім'ям 3 дітьми» передбачено, що громадяни України, в сім'ях яких виховуються та проживають неповнолітні діти, мають право на такі види державної допомоги: допомога у зв'язку з вагітністю та пологами; допомога при народженні дитини; допомога при усиновленні дитини; допомога по догляду за дитиною до досягнення нею трирічного віку; допомога на дітей, над якими встановлено опіку чи піклування; допомога на дітей одиноким матерям [8].

У разі виїзду одного з батьків за кордон на постійне проживання у державу, з якою Україна не має договору про надання правової допомоги, аліменти стягуються в порядку, встановленому Кабінетом Міністрів України. Згідно 3 цим Порядком, той 3 батьків, хто виїжджає, повинен виконати аліментні зобов'язання 3 утримання дитини (дітей) до досягнення нею, які оформляються договором між цією особою та одним 3 батьків, 3 яким залишається дитина (діти), або іï опікуном, піклувальником, або договором про припинення права на аліменти для дитини (дітей) у зв'язку 3 передачею права власності на нерухоме майно (житловий будинок, квартиру, земельну ділянку тощо). Якщо аліментні зобов'язання не були виконані особою, що виїжджає, стягнення аліментів провадиться за рішенням суду [9].

Вагому частину аліментних правовідносин займають правовідносини батьків та їх повнолітніх дітей. Ці правовідносини мають власні підстави виникнення, строки існування, припинення, а також зміст, права та обов'язки їх учасників.

Відповідно до СК України обов'язок батьків щодо утримання виникає стосовно: а) повнолітніх непрацездатних дочки, сина (ст. 198 СК України); 2) повнолітніх дочки, сина, які продовжують навчання (ст. 199 СК України).

Керуючись ст. 198 СК України, батьки зобов'язані утримувати своїх повнолітніх непрацездатних дочку, сина, які потребують матеріальної допомоги, якщо вони можуть таку матеріальну допомогу надавати. Вказані у кодексі юридичні факти у своїй сукупності утворюють складну юридичну сукупність. Непрацездатними $€$ ті, хто досяг встановленого законом пенсійного віку, інваліди 1-3 груп. Потреба у матеріальній допомозі визначається відповідно до прожиткового мінімуму, те ж стосується можливості надання допомоги. Можливість батьків надавати матеріальну допомогу не залежить від їхньої працездатності. Цей факт може бути враховано судом при винесенні рішення, але не звільняє зобов'язану особу від надання утримання. Аліменти повнолітнім непрацездатним доньці, сину, що потребують матеріальної допомоги, в разі визнання ї інвалідами першої, другої та третьої груп присуджуються на строк інвалідності, а непрацездатним за віком довічно.

За інших умов, повнолітнім доньці, сину не потрібно бути недієздатними для надання допомоги

Підставою для припинення права на утримання $€$ припинення навчання з будь-якої причини, а також досягнення 23-річного віку.

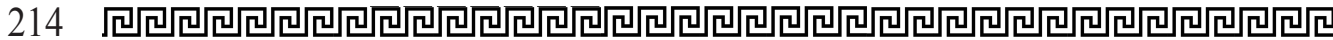


Крім того, до відносин між батьками і дочкою, сином щодо надання їм утримання застосовуються норми статей 187, 189-192 і 194-197 СК України. Це статті, що регулюють відносини щодо відрахування аліментів за ініціативою платника, договір про сплату аліментів та про припинення такої сплати у зв'язку з набуттям права власності на нерухоме майно, час, за який присуджуються аліменти, їх розмір та порядок зміни такого розміру і т.д.

Необхідно підсумувати,отже, можна зробити висновок, що відносини між батьками та дітьми щодо утримання останніх повинні підлягати більш ретельному регулюванню. На відміну від відносин подружжя, найважливіший суб’єкт цих відносин - дитина, що беззаперечно потребує підвищеного захисту та підтримки. 3 аналізу судової практики виходить, що суди у більшості випадків стають як раз на захист інтересів дітей, відмовляючи у позовних вимогах тільки у крайніх випадках, коли вони є абсолютно не обгрунтованими чи неможливими.

Стаття присвячена аналізу норм діючого законодавства та судової практики щодо питань аліментних зобов'язань, а саме обов'язку батьків утримувати дитину, зокрема, виплачувати аліменти. Проаналізовано порядок визначення розміру аліментів, порядок їх стягнення, випадки припинення обов'язку сплачувати аліменти на дитину. Окрема увага приділена можливості укладення договору між батьками на утримання неповнолітньої дитини, який може передбачати як грошову, так $і$ натуральну форму виплати аліментів (або ж комбінацію цзих двох форм). Той з батьків, з ким проживає дитина, $i$ той із батьків, хто проживає окремо від неї, з дозволу органу опіки та піклування можуть укласти договір про припинення права на аліменти для дитини у зв'язку з передачею права власності на нерухоме майно.
Встановлено, що мінімальний розмір утримання, визначений у законі, не достатньо виконує свою функиію забезпечення прав дітей - його сліо підвищити у сучасних економічних умовах. Разом з тим, зайвим було б встановлення в законі утримання у частизі від заробітку, адже у випадку надзвичайно маленького доходу дитина не буде отримувати необхідних для існування коштів, а у випадку великих доходів є висока вірогідність того, що вони будуть йти не тільки на забезпечення дитини.

Визнання аліментів, одержаних на дитину власністю дитини, що дає їй можливість брати участь у ї використанні або самостійно розпоряджуватися аліментами на ї утримання є можна розцінювати як додаткову гарантію того, що кошти не будуть використані не за призначенням.

Зроблено висновок про те, щзо відносини між батьками та дітьми щодо утримання останніх повинні підлягати більи ретельному регулюванню. На відміну від відносин подружжя, найважливіший суб'єкт изих відносин - дитина, щзо беззаперечно потребує підвищеного захисту та підтримки. 3 аналізу судової практики виходить, що суди у більшості випадків стають як раз на захист інтересів дітей, відмовляючи у позовних вимогах тільки у крайніх випадках, коли вони є абсолютно не обтрунтованими чи неможливими.

Ключові слова: дитина, аліменти, зобов'язання щодо аліментів, утримання дитини.

Adamova O. TO THE QUESTION OF THE DUTIES OF THE PARENTS TO MAINTAIN THE BABY

The article focuses on the analysis of current law and case law on alimony obligations, namely the obligation of parents to support a child, in particular, to pay alimony. The procedure for determining the amount of alimony, the procedure for collecting it, the 


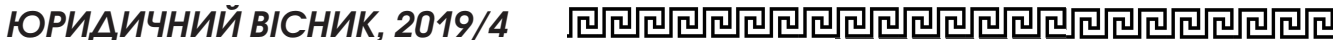

cases of termination of the obligation to pay child support for child support are analyzed. Particular attention is paid to the possibility of concluding a contract between the parents for the maintenance of a minor child, which may provide for both monetary and in-kind child support payments (or a combination of the two). The parent with whom the child resides and the parent who lives separately from the child may, with the permission of the guardianship authority, conclude an agreement to terminate the child support right in connection with the transfer of ownership of the real property.

It is established that the minimum amount of detention stipulated by law does not sufficiently fulfill its function of ensuring the rights of children - it should be raised in the current economic conditions. At the same time, it would be superfluous to establish a statutory withholding allowance because, in the case of extremely low income, the child will not receive the necessary subsistence funds, and in the case of large incomes, it is highly probable that they will go not only to provide for the child.

Recognition of child support received by a child that enables him or her to participate in their use or to self-administer child support can be regarded as an additional guarantee that the funds will not be used unintentionally.

It is concluded that the relationship between parents and children regarding the maintenance of the latter should be more carefully regulated. Unlike the relationship of the couple, the most important subject of this relationship is the child, who clearly needs increased protection and support. It is clear from the case-law that in most cases the courts are just protecting the interests of the children, refusing claims only in extreme cases where they are completely unjustified or impossible.

Key words: child, alimony, alimony obligations, child support.

\section{Література}

1. Сімейнии кодекс Украӥни віо 10.01.2002 p. Режuм docmyny: https: / / zakon.rada.gov.ua/laws / show/2947-14

2. Єфременко B.B. Сторони у справах про стягнення аліментів на дітей. Режим docmyny: file: / / / C: / Users /\% D0\%A1\%DO $\%$ B5\% D1\% 80\% D0\% B3\% D0\% B5\% D0\% B9। Downloads /FP_index.htm_2007_3_19.pdf

3. Рішення Кременецького районного суду Тернопільської області від 21.12.2011 p. по справі № 1909/2-1299/11. Pежим docmyny: http: / / www.revestr.court. gov.ua / Review / 20430765

4. Короткова Л.П. Яким має бути розмір аліментів на дітей. Право України. 1992. № 8. C. 21-23.

5. Афанасьева Л.В. Аліментні правовідносини в Україні: моногр. Луганськ: РВВ ЛДУВС, 2006. 224 с.

6. Чернишин I. В Україні змінюеться законодавство щодо стягнення аліментів. Pежим docmyny: https://jur.zp.ua/news/ v-ukrayini-zminyuyetsya-zakonodavstvoshhodo-styagnennya-alimentiv

7. Про затвердження Порядку призначення та виплати тимчасової державної допомоги дітям, батьки яких ухиляються від сплати аліментів, не мають можливості утримувати дитину або місие проживання ї невідоме: постановою Кабінету Міністрів України від 22.02.2006 р. Режим docmyny: https: / / zakon.rada.gov.ua/ laws / show / 189-2006-\% D0\% BF

8. Про державну допомогу сім'ям з дітьми: Закон України від 21.11.1992 р. Peжuм docmyny: https://zakon.rada.gov. ua/laws / main/2811-12

9. Про затвердження Порядку стягнення аліментів на дитину (дітей) у разі виїзу одного з батьків для постійного проживання в іноземній державі, з якою не укладено договір про подання правової допомоги: Постанова Кабінету Міністрів України від 19.08.2002 р. Режим docmyny: https: / / zakon.rada.gov.ua/ laws / main / 1203-2002-\% D0\% BF 